\title{
Methylation of phenol by chloromethane in the fungus Phellinus pomaceus
}

\author{
KIERAN J. MCNALlY ${ }^{1}$ and David B. HARPER ${ }^{1,2 *}$ \\ 'Department of Food and Agricultural Chemistry, The Queen's University of Belfast, Newforge Lane, \\ Belfast BT9 5PX, UK \\ ${ }^{2}$ Food and Agricultural Chemistry Research Division, Department of Agriculture for Northern Ireland, Newforge Lane, \\ Belfast BT9 5PX, UK
}

\begin{abstract}
The kinetics of phenol methylation by chloromethane $\left(\mathrm{CH}_{3} \mathrm{Cl}\right)$ in intact mycelia of the fungus Phellinus pomaceus were examined. Anisole was produced linearly with respect to time at a rate of $6.3 \mathrm{nmol} \mathrm{g}^{-1} \mathrm{~h}^{-1}$ over $16 \mathrm{~h}$ when washed mycelia were incubated with phenol and $\mathrm{C}^{2} \mathrm{H}_{3} \mathrm{Cl}$. Incorporation of $\mathrm{C}^{2} \mathrm{H}_{3}$ - label into anisole attained a plateau value of $27 \%$ within $2 \mathrm{~h}$. The rate of anisole production under $\mathrm{N}_{2}$ was only $36 \%$ of that in air, and the proportion of $\mathrm{C}^{2} \mathrm{H}_{3}$ - label incorporated from exogenous $\mathrm{C}^{2} \mathrm{H}_{3}$ - increased from 30 to $45 \%$ under these conditions. The rate of methylation attained a maximum in $10 \mathrm{mM}$-phenol, but the level of activity was only about $10 \%$ of that of the fungal carboxyl-methylating system. The presence of exogenous $\mathrm{C}^{2} \mathrm{H}_{3} \mathrm{Cl}$ clearly stimulated anisole formation, demonstrating that the rate of $\mathrm{CH}_{3} \mathrm{Cl}$ biosynthesis limited methylation to some extent. In contrast to the carboxyl-methylating system, no significant inhibition of methylation was observed at methyl acceptor concentrations up to $17.5 \mathrm{mM}$, and no sharp fall in the rate of gaseous $\mathrm{C}^{2} \mathrm{H}_{3} \mathrm{Cl}$ release or rapid increase in $\mathrm{C}^{2} \mathrm{H}_{3}$ incorporation were observed at supraoptimal concentrations of acceptor, indicating that endogenous $\mathrm{CH}_{3} \mathrm{Cl}$ biosynthesis was not inhibited under these conditions. Investigations of the rate of $\mathrm{C}^{2} \mathrm{H}_{3}$ - incorporation into anisole from exogenous $\mathrm{C}^{2} \mathrm{H}_{3} \mathrm{Cl}$ showed a linear relationship between the logarithm of $\% \mathrm{C}^{2} \mathrm{H}_{3}$ - incorporation and the logarithm of $\mathrm{C}^{2} \mathrm{H}_{3} \mathrm{Cl}$ concentration, suggesting that, as postulated for the carboxyl-methylating system, the $\mathrm{CH}_{3} \mathrm{Cl}$-synthesizing and $\mathrm{CH}_{3} \mathrm{Cl}$-utilizing enzyme systems were situated on either side of a membrane within the cell.
\end{abstract}

\section{Introduction}

Gaseous chloromethane $\left(\mathrm{CH}_{3} \mathrm{Cl}\right)$ is released during the idiophase by mycelia of most species of the Hymenochaetaceae, a widespread family of wood-rotting fungi (Harper, 1985; Harper \& Kennedy, 1986; Harper et al., 1988). The compound is produced in particularly high yield by species of the genus Phellinus, many of which also biosynthesize methyl esters of benzoic, salicylic and furoic acids as natural products (Harper et al., 1988). Using $\mathrm{C}^{2} \mathrm{H}_{3}$-labelled methionine, Harper \& Hamilton (1988) showed that ester formation and $\mathrm{CH}_{3} \mathrm{Cl}$ biosynthesis were biochemically linked in Phellinus pomaceus. These investigations culminated in the discovery that $\mathrm{CH}_{3} \mathrm{Cl}$ acts as a methyl donor in methylation of benzoic and furoic acids during primary metabolism of the fungus (Harper et al., 1989). The kinetics of the system in intact mycelia with reference to both benzoic acid and the non-physiological substrate butyric acid have been defined by McNally et al. (1990).

Methylation of compounds other than carboxylic acids by $\mathrm{CH}_{3} \mathrm{Cl}$ was also observed in $P$. pomaceus (Harper $\boldsymbol{e t}$ al., 1989). $\mathrm{A} \mathrm{CH}_{3} \mathrm{Cl}$-utilizing system capable of methylat- ing a variety of substituted phenols and thiophenol has been identified in the fungus. Although the system displayed some activity in the growth phase, maximum activity was associated with the idiophase, when a sudden fourfold increase occurred, clearly demonstrating that the system was biochemically distinct from the carboxylic acid-methylating system which attains maximum activity in mid growth phase. Levels of $\mathrm{C}^{2} \mathrm{H}_{3}$ incorporation from exogenous $\mathrm{C}^{2} \mathrm{H}_{3} \mathrm{Cl}$ into anisole were generally lower than those into methyl ester suggesting an even tighter channelling of $\mathrm{CH}_{3} \mathrm{Cl}$ during phenol methylation than that observed during carboxylic acidmethylation. Although the natural substrate of the phenol-methylating system has yet to be identified, the attainment of maximum activity in the idiophase implies that the enzyme is involved in secondary metabolism. In this context it is perhaps significant that a recent report by Harper et al. (1990) suggests that $\mathrm{CH}_{3} \mathrm{Cl}$ participates in the biosynthesis of veratryl alcohol, a key idiolyte produced by several species of white rot fungi in the Corticaceae and Polyporaceae, and in particular by Phanerochaete chrysosporium (Lundquist \& Kirk, 1978). Veratryl alcohol induces components of the ligninolytic 
system (Faison \& Kirk, 1985; Faison et al., 1986; Leisola et al., 1984), prevents inactivation of ligninase (Hammerli et al., 1986 b; Tonon \& Odier, 1988) and is reported to enhance the oxidation of lignin by lignin peroxidase in vitro (Hammerli et al., 1986a). It may also function as a one-electron redox mediator in the depolymerization process, possibly promoting oxidation by the creation of activated oxygen species (Harvey et al., 1986; Schoemaker et al., 1985). Although veratryl alcohol has not been reported as occurring in $P$. pomaceus or indeed any species of the Hymenochaetaceae, the phenol-methylating system present in $P$. pomaceus may be involved in the biosynthesis of methoxylated aromatic secondary metabolites with an analogous role to that of veratryl alcohol in lignin degradation by $P$. chrysosporium.

In this paper we describe further investigations of the phenol-methylating system in intact mycelia of $P$. pomaceus, with particular reference to the effect of $\mathrm{C}^{2} \mathrm{H}_{3} \mathrm{Cl}$ and phenol concentration on the rate of methylation and the incorporation of $\mathrm{C}^{2} \mathrm{H}_{3}$ - into anisole. The effect of phenol concentration on release of $\mathrm{CH}_{3} \mathrm{Cl}$ by mycelia has also been examined. The results of these studies are compared with those reported for the carboxylic acid-methylating system by McNally et al. (1990).

\section{Methods}

Organisms and maintenance media. Phellinus pomaceus (Pers.) Maire (NCWRF-FPRL 33A) was used in this study and maintained as described by McNally et al. (1990).

Chemicals. $\mathrm{C}^{2} \mathrm{H}_{3} \mathrm{Cl}\left(99.9\right.$ atom $\left.\%{ }^{2} \mathrm{H}\right)$ was purchased from MSD Isotopes, Montreal, Canada. Chloromethane and agarose '10' Electran were obtained from $\mathrm{BDH}$, and anisole was acquired from Aldrich.

Culture media and cultural conditions. The fungus was grown on glucose/mycological peptone/agarose medium overlaid with cellulose membrane as described by Harper et al. (1989).

Assay of methylating activity. Measurement of the rate of methylation of phenol by $P$. pomaceus and the percentage $\mathrm{C}^{2} \mathrm{H}_{3}$ - label incorporated into anisole was based on the standard assay procedure described by Harper et al. (1989) using $1 \mathrm{~mm}$-phenol as substrate and $1.23 \mathrm{~mm}$ $\mathrm{C}^{2} \mathrm{H}_{3} \mathrm{Cl}$ as methyl donor. In some experiments the concentrations of phenol and $\mathrm{C}^{2} \mathrm{H}_{3} \mathrm{Cl}$ were varied or the assay conducted under $\mathrm{N}_{2}$. In time-course studies, the assay was initiated by simultaneous injection of phenol and $\mathrm{C}^{2} \mathrm{H}_{3} \mathrm{Cl}$ into the vial, and incubation periods of 1 to $16 \mathrm{~h}$ were used. In all experiments, except those where standard deviations are quoted, assays were conducted in triplicate and the mean methylating activity expressed in nanomoles of anisole formed per $\mathrm{g}$ fresh wt of mycelium per hour $\left(\mathrm{nmol} \mathrm{g}^{-1} \mathrm{~h}^{-1}\right)$. Where the standard deviations of results are given, five replicates were employed.

Measurement of $\mathrm{CH}_{3} \mathrm{Cl}$ production by isolated mycelia. Production of $\mathrm{CH}_{3} \mathrm{Cl}$ by mycelia suspended in citrate buffer in the presence of phenol was measured by gas chromatography using a headspace technique (McNally et al., 1990).

Determination of anisole and of incorporation of $\mathrm{C}^{2} \mathrm{H}_{3}$ - into methoxyl group. Anisole formed in the assay solution was determined by a headspace technique. The solution $(1 \mathrm{ml})$ was placed in a $20 \mathrm{ml}$ vial sealed with a crimped cap and septum lined with PTFE. The headspace in the vial was analysed by gas chromatography/mass spectrometry using conditions identical to those described by McNally et al. (1990) for the analysis of methyl benzoate. The Mass Selective Detector was operated in the selected ion-monitoring mode, and the sum of the ion currents at $m / e 108$ and $m / e 111$ at the retention time of anisole was compared to a calibration graph obtained using authentic compound. The percentage incorporation of $\mathrm{C}^{2} \mathrm{H}_{3}$ - was measured as the ratio of ion currents

$$
\frac{m / e 111}{m / e 108+m / e 111}
$$

\section{Results and Discussion}

\section{Time course of methylation in washed mycelia}

Production of anisole with respect to time was linear for at least $16 \mathrm{~h}$ when mycelia of $P$. pomaceus were incubated with $1 \mathrm{~mm}$-phenol in the presence of $1.23 \mathrm{mM}-\mathrm{C}^{2} \mathrm{H}_{3} \mathrm{Cl}$ (Fig. 1). The $\mathrm{C}^{2} \mathrm{H}_{3}$ - label from exogenous $\mathrm{C}^{2} \mathrm{H}_{3} \mathrm{Cl}$ was rapidly incorporated into the methoxyl group of anisole, attaining a maximum value of about $27 \%$ within $2 \mathrm{~h}$, and thereafter remaining at approximately this level for the remainder of the incubation period. The rapid achievement of a plateau level of labelling mirrors the results obtained by McNally et al. (1990) in studies of the carboxylic acid-methylating system in the fungus, and confirms their conclusion that it is unlikely that $\mathrm{CH}_{3} \mathrm{Cl}$ undergoes conversion to a freely diffusible intermediate before acting as a substrate for the methylating system. Nevertheless, it is possible to envisage a mechanism in which a protein-bound intermediate is formed by alkylation of a thioether by $\mathrm{CH}_{3} \mathrm{Cl}$ to form a sulphonium derivative which then acts as methyl donor for the methylation of the phenolic hydroxyl.

When mycelia were incubated for $12 \mathrm{~h}$ with $1 \mathrm{~mm}$ phenol under standard assay conditions in the presence of nitrogen, instead of air, the rate of anisole formation fell from $8.4 \pm 1.0 \mathrm{nmol} \mathrm{g}^{-1} \mathrm{~h}^{-1}$ (mean $\pm \mathrm{SD}$ ) in air to $3.1 \pm 0.7 \mathrm{nmol} \mathrm{g}^{-1} \mathrm{~h}^{-1}$ under nitrogen, and the $\mathrm{C}^{2} \mathrm{H}_{3}-$ label in the anisole increased from $30 \pm 3 \%$ to $46 \pm 6 \%$. This effect can be attributed, as with the carboxylic acidmethylating system (McNally et al., 1990), to the known sensitivity of endogenous $\mathrm{CH}_{3} \mathrm{Cl}$ biosynthesis to oxygen limitation, rather than an effect on the methylating system per se.

\section{Effect of phenol concentration on anisole biosynthesis, \\ $\mathrm{C}^{2} \mathrm{H}_{3}$ - incorporation into anisole from exogenous $\mathrm{C}^{2} \mathrm{H}_{3} \mathrm{Cl}$, and $\mathrm{CH}_{3} \mathrm{Cl}$ release}

The influence of phenol concentrations up to $17.5 \mathrm{~mm}$ on anisole formation by washed mycelia of $P$. pomaceus in the presence and absence of $1.23 \mathrm{mM}-\mathrm{C}^{2} \mathrm{H}_{3} \mathrm{Cl}$ is shown in Fig 2(a). The rate of methylation was maximal at 


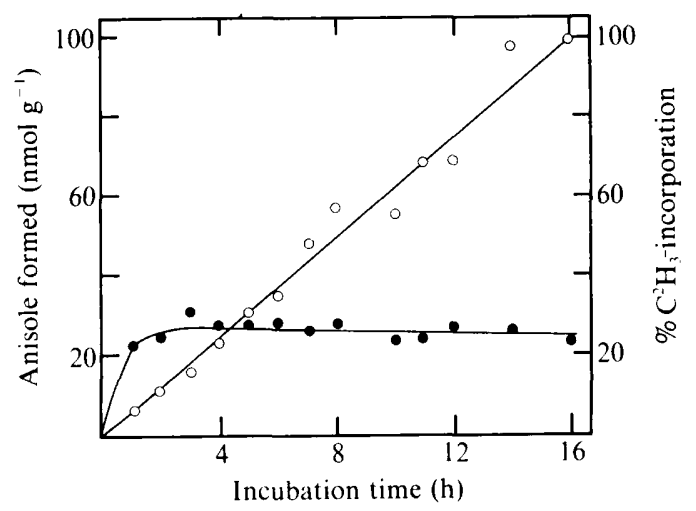

Fig. 1. Effect of incubation time on phenol methylation and incorporation of $\mathrm{C}^{2} \mathrm{H}_{3}$ - into anisole from exogenous $\mathrm{C}^{2} \mathrm{H}_{3} \mathrm{Cl}$ in washed mycelia of $P$. pomaceus. Washed mycelia were incubated as described in Methods with $1 \mathrm{~mm}$-phenol and $1.23 \mathrm{~mm}-\mathrm{C}^{2} \mathrm{H}_{3} \mathrm{Cl}$. Anisole formation and incorporation of $\mathrm{C}^{2} \mathrm{H}_{3}$ - into anisole were measured at intervals over $16 \mathrm{~h}$. $\mathrm{O}$, Anisole production; with $\mathrm{C}^{2} \mathrm{H}_{3}^{-}$.
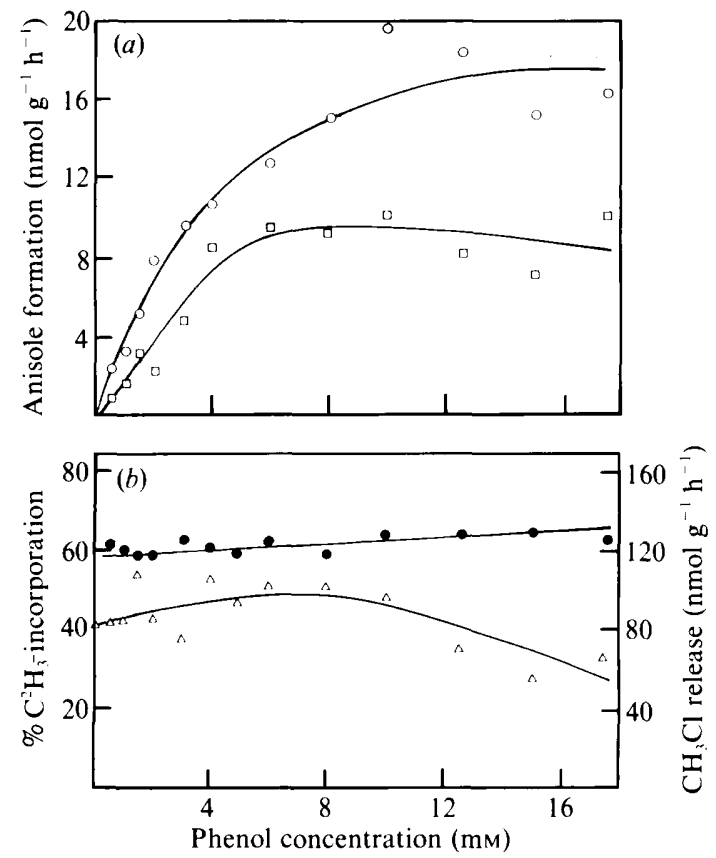

Fig. 2. Effect of phenol concentration in washed mycelia of $P$. pomaceus on $(a)$ anisole formation in the presence and absence of $\mathrm{C}^{2} \mathrm{H}_{3} \mathrm{Cl}$; and $(b)$ incorporation of $\mathrm{C}^{2} \mathrm{H}_{3}$ - label into anisole and release of $\mathrm{CH}_{3} \mathrm{Cl}$. Washed mycelia were incubated for $12 \mathrm{~h}$ as described in Methods with different concentrations of phenol in the presence and absence of $1.23 \mathrm{mM}^{-} \mathrm{C}^{2} \mathrm{H}_{3} \mathrm{Cl}$. Anisole production and incorporation of $\mathrm{C}^{2} \mathrm{H}_{3}$-into anisole were measured. In a separate experiment, mycelia of the same origin were incubated for $12 \mathrm{~h}$ (as described in Methods) in $20 \mathrm{mM}$ citrate buffer, $\mathrm{pH} 4 \cdot 0$, with different concentrations of phenol, and $\mathrm{CH}_{3} \mathrm{Cl}$ released by the mycelia was measured by gas chromatography. $\square$, Anisole production in absence of exogenous $\mathrm{C}^{2} \mathrm{H}_{3} \mathrm{Cl} ; \mathrm{O}$, anisole production in presence of $1.23 \mathrm{~mm}-\mathrm{C}^{2} \mathrm{H}_{3} \mathrm{Cl}$; , percentage of anisole labelled with $\mathrm{C}^{2} \mathrm{H}_{3}-\triangle \triangle, \mathrm{CH}_{3} \mathrm{Cl}$ released by mycelia. concentrations above $10 \mathrm{~mm}$, but the level of activity of the system was only about $10 \%$ of that of the carboxylic acid-methylation system reported by McNally et al. (1990); however, this comparatively low rate must be viewed in the context that phenol is almost certainly not the natural substrate of the system. The presence of $\mathrm{C}^{2} \mathrm{H}_{3} \mathrm{Cl}$ clearly stimulated anisole formation, indicating that as with the methylation of benzoic acid by the carboxylic acid-methylating system (Harper et al., 1989; McNally et al., 1990), the endogenous rate of $\mathrm{CH}_{3} \mathrm{Cl}$ biosynthesis limits the rate of methylation. However, unlike the situation with benzoic acid and to a lesser extent butyric acid, no inhibition of methylation by substrate concentrations up to $18 \mathrm{~mm}$ was observed.

Additionally, in contrast with carboxylic acid-methylation, no sharp fall in the rate of gaseous $\mathrm{CH}_{3} \mathrm{Cl}$ release or attendant rapid increase in $\mathrm{C}^{2} \mathrm{H}_{3}$ - incorporation into methylated product was displayed at supraoptimal concentrations of substrate, demonstrating that endogenous $\mathrm{CH}_{3} \mathrm{Cl}$ biosynthesis is not significantly inhibited by higher concentrations of substrate (Fig. $2 b$ ).

The failure of phenol to exercise the tight regulation of the activity of both the methylating system and the rate of $\mathrm{CH}_{3} \mathrm{Cl}$ biosynthesis that is shown by benzoic acid may possibly be ascribed to the fact that the maximum activity of the phenol-methylating system is associated with the idiophase, a stage where the precise control of the flux of metabolites characteristic of primary metabolism is not required. Alternatively, allosteric control of the system may be displayed only by the natural substrate of the system and not the non-physiological substrate, phenol, used in the assay.

\section{Effect of exogenous $\mathrm{C}^{2} \mathrm{H}_{3} \mathrm{Cl}$ concentration on anisole biosynthesis and incorporation of $\mathrm{C}^{2} \mathrm{H}_{3}$ -}

Washed mycelia were suspended in citrate buffer containing $1 \mathrm{mM}$-phenol with concentrations of $\mathrm{C}^{2} \mathrm{H}_{3} \mathrm{Cl}$ between $7.4 \mu \mathrm{M}$ and $2.6 \mathrm{~mm}$, and the rate of anisole formation together with the percentage $\mathrm{C}^{2} \mathrm{H}_{3}$ - incorporated into anisole were determined (Fig. 3). Phenol methylation was markedly stimulated by increased $\mathrm{C}^{2} \mathrm{H}_{3} \mathrm{Cl}$ concentration. However, above approximately $100 \mu \mathrm{M}$, the methylating system appeared to be saturated with $\mathrm{C}^{2} \mathrm{H}_{3} \mathrm{Cl}$. In this plateau region, a linear relationship $(\mathrm{r}=0.976, P<0.001)$ between the logarithm of $\% \mathrm{C}^{2} \mathrm{H}_{3}$ incorporation and the logarithm of exogenous $\mathrm{C}^{2} \mathrm{H}_{3} \mathrm{Cl}$ concentration is apparent, the interdependence being defined by the equation

$$
\begin{aligned}
\log \left[\% \mathrm{C}^{2} \mathrm{H}_{3} \text { - incorp. }\right]= & \log 4.55 \\
& +0.25 \log \left[\mathrm{C}^{2} \mathrm{H}_{3} \mathrm{Cl} \text { concn. }\right]
\end{aligned}
$$

This relationship is of the same form as that found with carboxyl methylation when the enzyme was saturated 


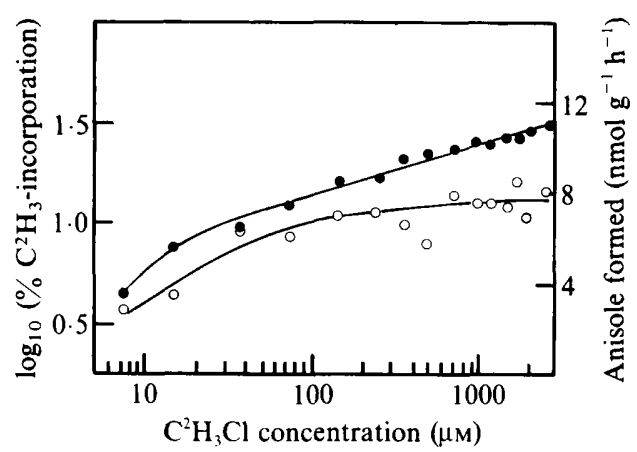

Fig. 3. Effect of exogenous $\mathrm{C}^{2} \mathrm{H}_{3} \mathrm{Cl}$ concentration on anisole formation and incorporation of $\mathrm{C}^{2} \mathrm{H}_{3}$ - label into anisole in washed mycelia of $P$. pomaceus. Washed mycelia were incubated as described in Methods with $1 \mathrm{mM}$-phenol and concentrations of $\mathrm{C}^{2} \mathrm{H}_{3} \mathrm{Cl}$ between $7.5 \mu \mathrm{M}$ and $2.4 \mathrm{mM}$. Anisole formation and incorporation of $\mathrm{C}^{2} \mathrm{H}_{3}$ - label into anisole were measured after $12 \mathrm{~h} . \mathrm{O}$, Anisole production; , logarithm (base 10) of \% anisole labelled with $\mathrm{C}^{2} \mathrm{H}_{3}$.

with either benzoic or butyric acid as substrate, and conforms to the empirically derived Freundlich adsorption isotherm employed to predict adsorption from the gas phase or solution at a solid interface. McNally et al. (1990) interpreted this finding as suggesting that within the cell exogenous $\mathrm{C}^{2} \mathrm{H}_{3} \mathrm{Cl}$ competes with endogenously synthesized $\mathrm{CH}_{3} \mathrm{Cl}$ at a membrane surface on opposite sides of which are located the $\mathrm{CH}_{3} \mathrm{Cl}$-biosynthesizing system and the $\mathrm{CH}_{3} \mathrm{Cl}$-utilizing system, each of them probably physically associated with the membrane. It would therefore appear that the phenol-methylating system, although biochemically distinct from the carboxyl-methylation system, is physically associated with the endogenous $\mathrm{CH}_{3} \mathrm{Cl}$-biosynthesizing enzyme in a manner very similar to that of the carboxyl-methylation system.

\section{References}

FAISON, B. D. \& KIRK, T. K. (1985). Factors involved in the regulation of ligninase activity in Phanerochaete chrysosporium. Applied and Environmental Microbiology 49, 299-304.
Faison, B. D., KirK, T. K. \& Farrell, R. L. (1986). Role of veratryl alcohol in regulating ligninase activity in Phanerochaete chrysosporium. Applied and Environmental Microbiology 52, 251-254.

Haemmerli, S. D., Leisola, M. S. A. \& Fiechter, A. (1986a). Polymerization of lignins by ligninases. FEMS Microbiology Letters 35, 33-36.

Haemmerli, S. D., Leisola, M. S. A., Sanglard, D. \& Fiechter, A. $(1986 b)$. Oxidation of benzo(a)pyrene by extracellular ligninases of Phanerochaete chrysosporium. Journal of Biological Chemistry 261, 6900-6903.

HARPER, D. B. (1985). Halomethane from halide ion - a highly efficient fungal conversion of environmental significance. Nature, London $315,55-57$.

HARPER, D. B. \& Hamilton, J. T. G. (1988). Biosynthesis of chloromethane in Phellinus pomaceus. Journal of General Microbiology 134, 2831-2839.

HARPER, D. B. \& KENNEDY, J. T. (1986). Effect of growth conditions on halomethane production by Phellinus species: biological and environmental implications. Journal of General Microbiology 132, 1231-1246.

Harper, D. B., Kennedy, J. T. \& Hamilton, J. T. G. (1988). Chloromethane biosynthesis in poroid fungi. Phytochemistry 27, 3147-3153

HaRper, D. B., Hamilton, J. T. G., Kennedy, J. T. \& McNally, K. J. (1989). Chloromethane, a novel methyl donor for biosynthesis of esters and anisoles in Phellinus pomaceus. Applied and Environmental Microbiology 55, 1981-1989.

Harper, D. B., Buswell, J. A., Kennedy, J. T. \& Hamilton, J. T. G. (1990). Chloromethane; methyl donor in veratryl alcohol biosynthesis in Phanerochaete chrysosporium and other lignin degrading fungi. Applied and Environmental Microbiology 56, 3450-3457.

Harvey, P. J., Schoemaker, H. E. \& Palmer, J. M. (1986). Veratryl alcohol as a mediator and the role of radical cations in lignin biodegradation by Phanerochaete chrysosporium. FEBS Letters 195, 242-246.

Leisola, M. S. A., Ulmer, D. C., Waldner, R. \& Fiechter, A. (1984). Role of veratryl alcohol in lignin degradation by Phanerochaete chrysosporium. Journal of Biotechnology 1, 331-339.

LundquisT, K. \& KIRK, T. K. (1978). De novo synthesis and decomposition of veratryl alcohol by a lignin degrading basidiomycete. Phytochemistry 17, 1676.

MCNally, K. J., Hamilton, J. T. G. \& Harper, D. B. (1990). The methylation of benzoic and n-butyric acids by chloromethane in Phellinus pomaceus. Journal of General Microbiology 136, 15091515.

Schoemaker, H. E., Harvey, P. J., Bowen, R. M. \& Palmer, J. M. (1985). On the mechanism of enzymatic lignin breakdown. FEBS Letters 183, 7-12.

TONON, F. \& ODIER, E. (1988). Influence of veratryl alcohol and hydrogen peroxide on ligninase activity and ligninase production by Phanerochaete chrysosporium. Applied and Environmental Microbiology 54, 466-472. 